\title{
Environmental determinants of diving beetle assemblages (Coleoptera: Dytiscidae) in an urban landscape
}

\author{
Wenfei Liao ${ }^{1}$ (D) $\cdot$ Stephen Venn ${ }^{1}$ (D) Jari Niemelä ${ }^{1}$ (D)
}

Received: 25 November 2019/Revised: 28 February 2020/Accepted: 31 March 2020 /

Published online: 9 April 2020

(C) The Author(s) 2020

\begin{abstract}
Blue infrastructure is an important component of urban green infrastructure, due to its capacity for water cycle regulation and soil formation, as well as supporting unique biodiversity. Urban ponds, as part of urban blue, can harbour a diverse assemblage of aquatic macroinvertebrates. As yet, it is not clear how urbanisation affects macroinvertebrate diversity. In this study, we focus on diving beetles (Dytiscidae) in the Helsinki Metropolitan Area, Finland, to investigate how urbanisation affects their diversity, as well as the effects of margin steepness and the presence or absence of fish on urban dytiscids. We sampled dytiscids using 1-L activity traps in 14 fishless ponds and 11 ponds with fish, at ten sites. We applied generalised linear mixed models (GLMM) and non-metric multidimensional scaling (NMDS) to analyse the effects on dytiscid assemblages. We found that urbanisation had a negative effect on species richness but not on abundance. Steepness of pond margins and the presence or absence of predatory fish, affected both species richness and abundance: dytiscids prefer ponds with gently sloping margins; they have $80 \%$ higher species richness and are $79 \%$ more abundant in fishless ponds, and medium to large-sized dytiscid species are more capable of coexisting with fish. Urban wetlands can support a diversity of dytiscids at the regional level, and the presence of ponds without predatory fish is beneficial for maintaining dytiscid diversity. We recommend maintaining a diverse range of ponds and wetland habitats for the maintenance of aquatic biodiversity in urban regions.
\end{abstract}

Keywords Biodiversity $\cdot$ Blue infrastructure $\cdot$ Dytiscid $\cdot$ Macroinvertebrate $\cdot$ Margin steepness · Urbanisation

Communicated by P. Ponel.

This article belongs to the Topical Collection: Urban biodiversity.

Wenfei Liao

wenfei.liao@helsinki.fi

1 Faculty of Biological and Environmental Sciences, University of Helsinki, P.O. Box 65, 00014 Helsinki, Finland 


\section{Introduction}

Interest in green infrastructure-networks of vegetated land surfaces-has increased with growing awareness of the broad range of benefits they provide for residents of urban regions, as perceived through the concepts of Ecosystem Services (Nesshöver et al. 2017) and Nature-Based Solutions (Eggermont et al. 2015; Tzoulas et al. 2007). Many of the benefits provided by green infrastructure are associated with hydrology, such as the storage, purification and controlled release of water (Eggermont et al. 2015), as a consequence of which blue infrastructure elements, such as water bodies, channels and wetland habitats, are important components of urban green infrastructure (Vierikko and Niemelä 2016). Although the "blue" component of green infrastructure is also essential to the ecology of cities (Maksimović et al. 2015; Hill et al. 2017; Holtmann et al. 2018) and for the wellbeing of urban residents (Sun et al. 2012; Völker et al. 2013; Völker and Kistemann 2015), its importance from both ecological and social aspects is often neglected (Hill and Wood 2014; Carter 2015).

Urban wetlands, as a type of urban blue, support a diverse variety of aquatic organisms (e.g. Hamer and Parris 2011; Murray et al. 2013; Wahlroos et al. 2015; Hill et al. 2017). Such habitats, however, are prone to the consequences of urbanisation, such as increasing extent of impermeable surfaces, loss of connectivity and the loss and fragmentation of habitats (Concepción et al. 2015). Extrinsic environmental factors can affect the permeability of the habitat matrix for aquatic organisms with a limited dispersal range, such as invertebrates. On the other hand, intrinsic environmental factors of urban wetland habitats can also reduce the diversity of their communities of aquatic organisms. Steepness of the pond margin, for instance, can affect macroinvertebrates, such as Dytiscidae, because their larvae prefer shallow water prior to pupation and most species pupate out of the water, in adjacent terrestrial habitats (Dolmen and Solem 2002; Kehl 2014). Furthermore, pond margins with steep slopes can be a challenge for mature larvae trying to access suitable habitats for pupation.

Most research on aquatic biodiversity in urban areas has focused on aquatic macroinvertebrates in general, while only a few studies have focussed on specific taxa, such as Odonata (e.g. Lubertazzi and Ginsberg 2010; Goertzen and Suhling 2013). Aerial dispersal is a vital strategy of aquatic macroinvertebrates to colonize new sites (Verberk et al. 2008). In the case of a region with small isolated ponds and harsh winters, as is the case in Helsinki, dispersal capacity can be critically important. Macroinvertebrates can be classified into active dispersers and passive dispersers. Active dispersers have wings and are capable of flight. They include, for instance, diving beetles (Dytiscidae), although some species also utilise anemochory, i.e. passive dispersal by wind for long-distance movement (Verberk et al. 2008). Passive dispersers may use anemochory or phoresy, i.e. using other animals as vectors, as their dispersal strategies. Dispersal mode and habitat connectivity are the main factors determining the assemblage structure of aquatic invertebrates (Meutter et al. 2007). Urban landscapes are affected by fragmentation, movement barriers and high contrast between adjacent habitat types. Increasing urbanization can create filters for macroinvertebrates with different dispersal capacities colonizing new sites (Concepción et al. 2015).

In this study, we focus on diving beetles (Dytiscidae), a family of aquatic insects that occur in urban wetlands (e.g. Lundkvist et al. 2002; Della Bella and Mancini 2009; Hill and Wood 2014). Our objective is to investigate how urbanization (extent of impermeable area around the wetlands) and factors of the aquatic environment (steepness of the pond 
margin and the presence or absence of fish), affect dytiscid diversity in urban wetlands. Our research questions are: (1) How does dytiscid diversity vary along an urban gradient? (2) Does steepness of the pond margin affect dytiscid assemblage composition? and (3) How does the presence or absence of fish affect dytiscid diversity?

\section{Materials and methods}

\section{Dytiscid ecology and study sites}

Dytiscids are predaceous in at least part of their life cycle. They feed on invertebrates and even some vertebrates, such as tadpoles and young fish, while they in turn are the prey of animals at higher trophic levels, such as fish, amphibians, birds, and mammals (Culler et al. 2014). Although dytiscids are generally capable of flight, flight capacity varies considerably between species (Bilton 2014). Lundkvist et al. (2002) have shown that dytiscids can fly a long distance to reach waterbodies in an urban landscape in Sweden and that some species, such as Agabus uliginosus, are relatively tolerant of urban landscapes. There are 142 dytiscid species in Finland, and 96 species in the Uusimaa Region (Rassi et al. 2015), where our study was performed.

In this study, we surveyed 25 urban ponds located at ten sites in the Helsinki Metropolitan Area $\left(60.1699^{\circ} \mathrm{N}, 24.9384^{\circ} \mathrm{E}\right.$; Fig. 1), Uusimaa, Finland. Five ponds were isolated (I1-I5) by at least $1 \mathrm{~km}$ from other ponds, while the remaining 20 ponds were in groups (G1-G5). Out of the 25 ponds, 14 ponds were fishless and 11 ponds had fish. Seventeen ponds were permanent, while eight ponds were seasonal. The maximum water depth of the ponds varied from approximately $0.5 \mathrm{~m}$ to $4 \mathrm{~m}$ deep. The size of the ponds

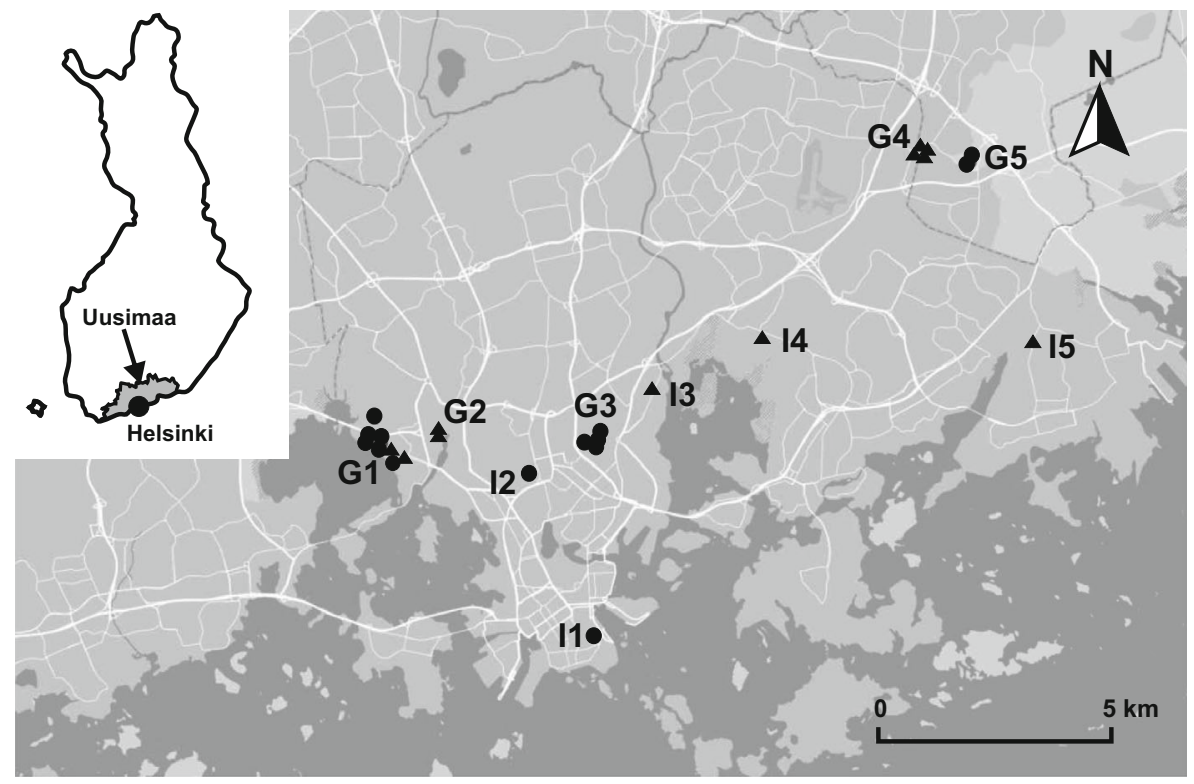

Fig. 1 A map of the study ponds in Helsinki, Uusimaa Region, Finland. The isolated ponds are labled with "I" (I1-I5), and sites with more than one pond in a cluster are labled with "G" (G1-G5). Ponds indicated with circles are fishless ponds, and ponds indicated with triangles are ponds with fish. The light grey areas are terrestrial, the dark grey areas are water, and the white lines are main roads 
varied from 0.013 hectare to 1.18 hectare (mean $=0.25 \pm 0.31$ hectare). The length of the shoreline varied from 59 to $559 \mathrm{~m}$ (mean $=206 \pm 136 \mathrm{~m})$. The proportion of impermeable surface in a $500 \mathrm{~m}$ buffer zone varied from $15.95 \%$ to $56.41 \%$ (mean $=28.80 \% \pm$ $10.19 \%$ ). These ponds have values of supporting biodiversity and providing recreational opportunities, such as bird watching and fishing. They had received little or no management during the study period.

\section{Sampling methods}

To explore how urbanisation, steepness of pond margins, and the presence of fish affect dytiscid diversity, we sampled diving beetles during May 2018 using 1-L activity traps without bait. The activity traps comprised a 1-L glass jar and a funnel of $10 \mathrm{~cm}$ diameter at the large end and $2.3 \mathrm{~cm}$ at the narrow end. We set the traps horizontally and operated them for $48 \mathrm{~h}$. The depth where the traps were operated was $34.17 \pm 21.58 \mathrm{~cm}$ beneath the water surface. The number of traps in each pond varied between 5 and 15, depending on the size of the pond (shoreline perimeter in May, Appendix 1). We also sampled during July, to investigate how the three environmental factors affected dytiscid assemblage compositions. We set fewer traps in July due to the reductions in pond size (withdrawing shoreline and decreasing perimeter). The dytiscid specimens caught in the traps were preserved in 70\% ethanol and identified to species according to Nilsson and Holmen (1995) using a microscope. The nomenclature of dytiscid species follows Nilsson and Hájek (2018).

We recorded the extent of impermeable surface in a $500 \mathrm{~m}$ buffer and a $1000 \mathrm{~m}$ buffer as indicators of urbanisation (HSY 2016), though we only used the value from the $500 \mathrm{~m}$ buffer, due to the strong collinearity between these two values. To explore how steepness of pond margins affects dytiscid assemblages, we measured the water depths at distances of $0.5 \mathrm{~m}, 1.0 \mathrm{~m}, 1.5 \mathrm{~m}$, and $2.0 \mathrm{~m}$ from the margin in early May 2018. We estimated margin steepness using these values (Appendix 2). Due to the strong collinearity between the four sets of data, we only used margin steepness at $1.0 \mathrm{~m}$ from the shore in data analysis, because that was approximately where we set the activity traps. We set a fish trap for $24 \mathrm{~h}$ in all permanent ponds to determine the presence or absence of fish.

\section{Statistical analysis}

In total, we obtained 201 records from the activity traps in May, of which 107 traps (53\%) were empty. We used the R software (R Core Team 2018) for all the statistical analyses. In the data exploration, we excluded three records in one fishless pond as outliers, because the margin steepness was approximately $58^{\circ}$, which was more than $10^{\circ}$ steeper than the rest of the ponds. We used the "glmmTMB" package (Brooks et al. 2017) to model how urbanisation, margin steepness, and the presence or absence of fish affected dytiscid species richness and abundance. Considering dytiscids are more vulnerable in ponds with than without fish, we included the interaction between the presence or absence of fish and water depth as a covariate. Our data are two-way nested: traps are nested within pond, and ponds are nested within site; therefore, we included site and pond as random effects. The equations of the full models are described in Appendix 3. During the model selection stage, we did a backward selection manually and chose the optimal model based on the lowest Akaike information criterion (AIC) values (Appendix 3). We simulated 10,000 datasets 
with the optimal models for model validation to ensure that there was no need to run zeroinflated models (Zuur and Ieno 2016).

We pooled the monthly observations of each pond. In total, we obtained 20 dytiscid assemblage samples in May and 14 samples in July. We used the "vegan" package to apply a non-metric multidimensional scaling (NMDS) analysis with Bray-Curtis dissimilarities (Oksanen et al. 2018). We fitted the environmental factors to the NMDS analysis, to investigate how they affected dytiscid assemblage composition. These environmental factors included urbanisation, average steepness of the pond margin, presence and absence of fish, and month of sampling.

\section{Results}

In our study wetlands, we recorded 39 out of 96 dytiscid species $(40.63 \%)$ that are known from the Uusimaa Region. In total, we obtained 525 dytiscid individuals of 39 species (402 individuals of 37 species in May and 123 individuals of 24 species in July). Agabus affinis, A. congener, Cybister lateralimarginalis, Graptodytes granularis, Hydroporus angustatus, H. discretus, H. memnonius, H. notatus, H. pubescens, Hygrotus impressopunctatus, Ilybius angustior, I. guttiger, I. subtilis, I. wasastjernai, and Suphrodytes dorsalis, were only recorded in May. Ilybius fuliginosus $(\mathrm{n}=1)$ and Rhantus suturellus $(\mathrm{n}=1)$, were only recorded in July. In May, there were $0.92 \pm 2.49$ individuals per trap and $0.51 \pm 1.20$ species per trap in ponds with fish, and $3.43 \pm 4.22$ individuals per trap and $1.92 \pm 1.85$ species per trap in fishless ponds. The fish species in our ponds were all predatory fish: Crucian carp (Carassius carassius), Prussian carp (C. gibelio), tench (Tinca tinca), European perch (Perca fluciatilis), and northern pike (Esox lucius).

\section{Dytiscid species richness}

The optimal GLMM Poisson model result (Table 1) shows that urbanisation (extent of impermeable area around the ponds) had a significantly negative effect on diving beetle species richness ( $p=0.041$, Fig. $2 \mathrm{a}, \mathrm{b}$ ). The presence of fish had a highly significant and negative effect on species richness compared with the absence of fish $(p=0.001)$; the presence of fish had a stronger effect on dytiscid species richness than urbanisation and

Table 1 The result of the optimal Poisson GLMM model for dytiscid species richness

\begin{tabular}{|c|c|c|c|c|c|c|}
\hline & \multicolumn{4}{|l|}{ Fixed part } & \multicolumn{2}{|l|}{ Random part } \\
\hline & Estimate & SE & Z-value & P-value & Random Effects & Variance \\
\hline Intercept & 0.27 & 0.32 & 0.85 & 0.396 & Pond & $0.74^{2}$ \\
\hline UR500 & -0.41 & 0.20 & -2.04 & 0.041 & Site & $0.30^{2}$ \\
\hline Steepness & -0.09 & 0.17 & -0.52 & 0.602 & & \\
\hline Fish & -1.48 & 0.46 & -3.24 & 0.001 & & \\
\hline Steepness:Fish & -0.96 & 0.27 & -3.51 & $<0.001$ & & \\
\hline
\end{tabular}

SE means standard error. "UR500" indicates the urbanisation within the $500 \mathrm{~m}$ buffer zone. "Steepness" means steepness of the pond margin. "Fish" means the presence of fish, and "Fishless" is the intercept, as a reference level. "Steepness:Fish" indicates the interaction between margin steepness and presence of fish. The bold $p$-values indicate statistical significance. The same in Table 2 

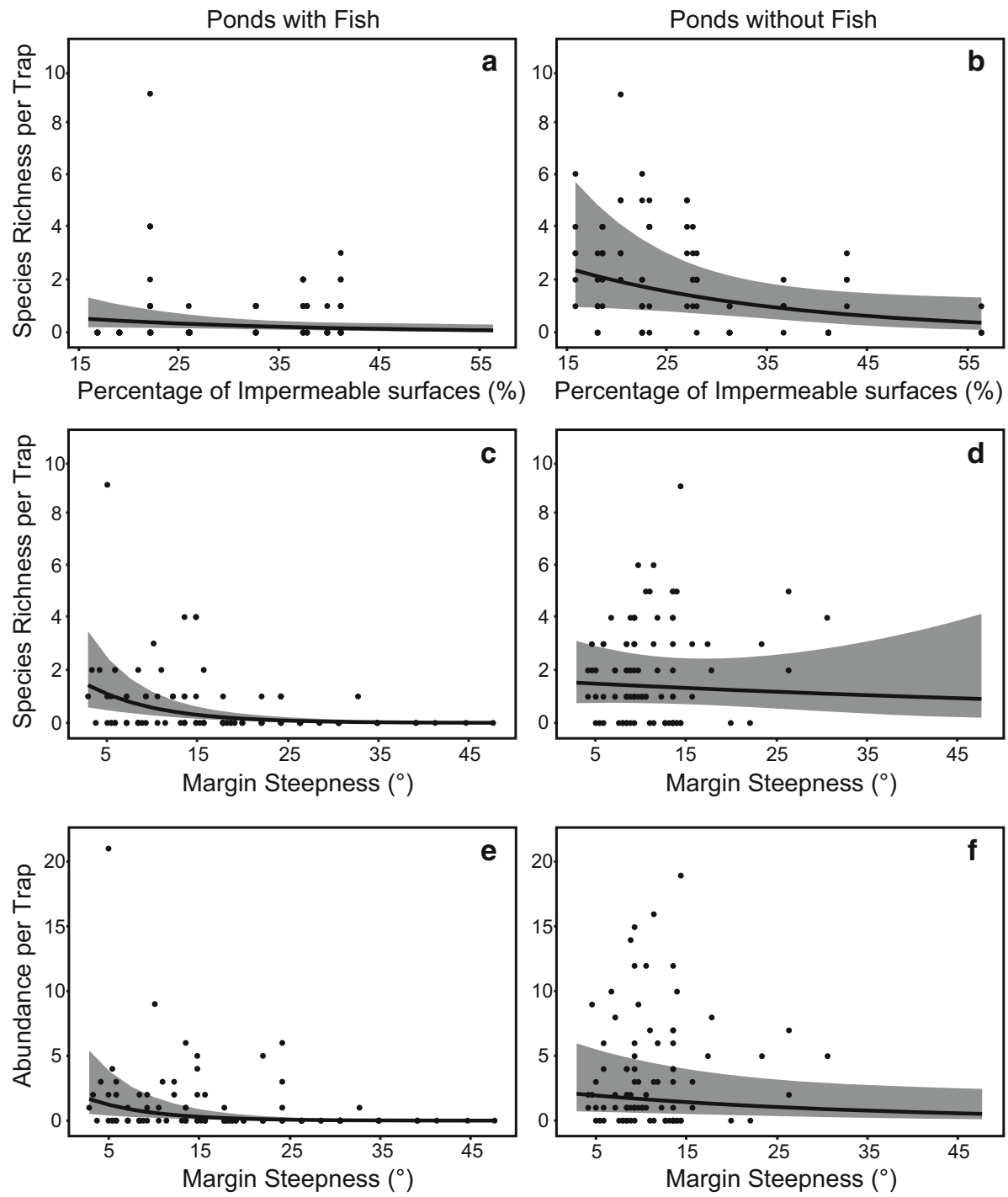

Fig. 2 The optimal Poisson GLMMs of dytiscid species richness (a-d) and abundance (e, f). With increasing urbanisation, dytiscid species richness decreased in ponds with (a) and without fish (b). With increasing steepness of the pond margin, species richness and abundance decreased in ponds with (c, e) and without fish (d, f). The grey bands represent the $95 \%$ confidence interval. The black dots represent observed data. The predictions of margin steepness over $35^{\circ}$ in fishless ponds and of urbanisation levels higher than $42 \%$ in ponds with fish may not be reliable, due to the scarcity of observations

steepness of the pond margin. Steepness of the pond margin did not have a statistically significant effect on dytiscid species richness in fishless ponds ( $p=0.602$, Fig. $2 \mathrm{c}, \mathrm{d})$ whereas the interaction between margin steepness and the presence of fish had a highly significant and negative effect on dytiscid species richness $(p<0.001)$. 
Table 2 The result of the optimal Poisson GLMM model for dytiscid abundance

\begin{tabular}{lrrrrrrr}
\hline Fixed part & & & & & & \multicolumn{2}{l}{ Random part } \\
\cline { 1 - 1 } & Estimate & SE & Z-value & P-value & & Random effects & Variance \\
\hline Intercept & 0.35 & 0.53 & 0.67 & 0.673 & & Pond & $1.21^{2}$ \\
Steepness & -0.25 & 0.14 & -1.80 & 0.071 & & Site & $0.78^{2}$ \\
Fish & -1.58 & 0.70 & -2.25 & $\mathbf{0 . 0 2 4}$ & & \\
Steepness:Fish & -0.90 & 0.23 & -3.96 & $\mathbf{< . 0 0 1}$ & & \\
\hline
\end{tabular}

\section{Dytiscid abundance}

Urbanisation had little influence on dytiscid abundance and was not included in the optimal model (Appendix 3). The optimal model (Table 2) showed that steepness of the pond margin did not have a statistically significant effect on dytiscid abundance $(p=0.071$; Fig. 2e, f). Dytiscid abundance was significantly higher in ponds without than with fish $(p=0.024)$. The interaction between margin steepness and the presence of fish had a highly significant and negative effect on abundance $(p<0.001)$.

\section{Dytiscid assemblage composition}

There was little change in dytiscid assemblage composition between May and July $\left(\mathrm{r}^{2}=0.04, p=0.283\right)$, and the steepness of the pond margin had little effect on dytiscid assemblages $\left(r^{2}=0.04, p=0.533\right)$. The dytiscid assemblages showed a significant response to urbanization within the $500 \mathrm{~m}$ buffer zone $\left(\mathrm{r}^{2}=0.32, p=0.003\right.$; Fig. 3a), and the presence or absence of fish $\left(\mathrm{r}^{2}=0.10, p=0.033\right.$; Fig. 3b). There was a threshold level of urbanization of approximately $36 \%$, above which most dytiscid species were absent, with the exception of Acilius canaliculatus and Agabus sturmii, which were more tolerant of urbanization than other species (Fig. 3a). Medium to large-sized species, such as Ilybius
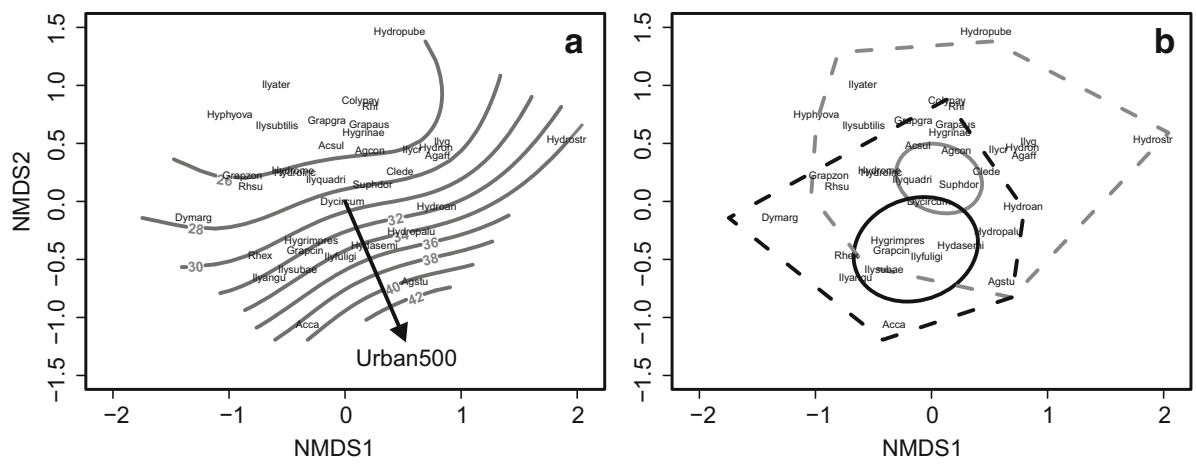

Fig. 3 NMDS of the dytiscid assemblage a with an urbanisation surface, urbanisation gradient from 26 to $42 \%$, and $\mathbf{b}$ with the presence (dark grey) or absence (light grey) of fish. The circles in b represent the $95 \%$ confidence interval of the dytiscid species occurrence in ponds with and without fish, and the polygons with dashed lines represent dytiscid communities in ponds with and without fish 
spp. and Dytiscus spp., were more capable of persisting in ponds with fish than small-sized species, such as Hydroporus spp. and Hyphydrus ovatus (Fig. 3b).

\section{Discussion}

In this study, we investigated the diving beetle assemblages of ponds in an urban region and examined the factors that affect their diversity. We found that both urbanisation and pond characteristics had an effect on dytiscid species richness, while abundance was only affected by the pond characteristics. There were notable differences between the responses of species richness and abundance to urbanisation, with urbanisation having an effect on assemblage structure. Steepness of the pond margin had stronger effects on dytiscid diversity in ponds with, than those without fish. The presence or absence of fish has an effect on both diversity and assemblage structure.

\section{Urbanisation effects}

Urbanisation negatively affected dytiscid species richness but had no significant effect on abundance. This suggests that urbanisation does not reduce the capacity of ponds to support dytiscids, as the number of individuals was unchanged but that some species respond negatively to urbanisation. Our results are inconsistent with a number of previous studies that report no significant relationship between urbanisation and aquatic macroinvertebrate diversity (e.g. Lubertazzi and Ginsberg 2010; Hill and Wood 2014). However, the methods employed for estimating urbanisation in those studies may have affected the results. Lubertazzi and Ginsberg (2010) used chloride concentration as their measurement of urbanisation. Some studies (e.g. Hill and Wood 2014; Lundkvist et al. 2002) used subjective land-use categories, such as urban, suburban, agricultural, and conservation areas, and reported negative effects of urbanisation on aquatic macroinvertebrates on a larger scale. In this study, we used the amount of hard surface within a $500 \mathrm{~m}$ buffer zone to investigate the effect of urbanisation on dytiscids in an urban landscape on a finer scale. We analysed species richness and abundance separately, instead of using diversity indices, as applied in the studies of Lubertazzi and Ginsberg (2010) and Hill and Wood (2014). We suggest that comparisons of diversity indices for the purpose of comparing assemblages is inadequate, as if there are similar changes in both abundance and species richness then these changes will not be detected by using diversity indices. We therefore recommend using a more sensitive approach, such as the mixed modelling method applied here to analyse species richness and abundance respectively.

Changes in dytiscid diversity in response to urbanization could be due to differences between the ponds or differences in the environment around the ponds. Our finding that abundance was not affected suggests that the ponds' capacity to support dytiscids was unaffected, regardless of the extent of urbanization. The smaller number of species recorded in more urban ponds, however, indicates that some species are intolerant of urbanisation. The reasons for the difference in species richness probably lie in both the internal and the external environment. Urbanization may affect dytiscid assemblages through water quality, as a consequence of stormwater run-off from adjacent impermeable surfaces, or through the channelization and modification of small water bodies (Zalewski and Wagner 2008; Hassall and Anderson 2015). Urban wetlands generally suffer from varying levels of water pollution, depending on such factors as land-use and the age of the wetlands (Sharley et al. 2017). Furthermore, wetland modification, such as the removal of 
vegetation and hardening of pond edges, can remove habitat features that are important for aquatic macroinvertebrates (Hassall 2014; Noble and Hassall 2015). In a future study, we plan to investigate the environmental factors affecting urban ponds and their effects on dytiscid assemblages.

In this study, we used the proportion of impermeable surface within a $500 \mathrm{~m}$ buffer zone as our indicator of the external environment of the ponds, which also indicates the permeability of the matrix to dispersal. We assume that ponds with highly urbanized buffer zones are difficult to colonise. Dytiscids are known to mostly fly at relatively low heights (Wahlberg and Solbreck 2013; Stork et al. 2016) and they disperse more frequently in open landscapes than in forested landscapes (Nilsson and Svensson 1995; Lundkvist et al. 2002; Schäfer et al. 2006). Schäfer et al. (2006) propose that the preference of dytiscids for open landscapes is due to better visibility of wetlands in open surroundings than in shaded surroundings. This suggests that also urban infrastructure can be a major obstacle to the dispersal of many dytiscid species. Another disruptive factor can be the influence of other artificial surfaces. For instance, Nilsson (1997) reported that car roofs attract large numbers of dispersing dytiscids, especially Hydroporus incognitus, and it has also been suggested that roads can be an ecological trap for dytiscids (Muñoz et al. 2015). In urban areas, there is a greater risk of dispersing dytiscids being deceived by such pseudohabitats.

Different dytiscid species have different threshold levels of urbanisation (Fig. 3a; Appendix 3). Most species, including Ilybius spp. and Hydroporus spp., only become established in ponds with a level of urbanisation of less than $36 \%$; Acilius canaliculatus and Agabus sturmii, however, were more tolerant and had a threshold in excess of $38 \%$. As species with limited flight capacity are present in the regional pool of species, the most likely reason for their absence from ponds with a higher level of urbanisation is due to poor dispersal capacity and more hostile habitat around the ponds. For species with strong flight capacity, such as A. canaliculatus (Nilsson and Holmen 1995), the permeability of the habitat matrix may be less important than it is for species with limited flight capacity, such as Graphoderus zonatus (Eriksson 1972). For these species, there is a small probability of successful dispersal in a habitat matrix with poor permeability. Habitat permeability of the matrix and the distance between suitable habitats are likely to be critical factors for species with poor dispersal capacity (Iversen et al. 2013). Maintaining connectivity between ponds, however, is highly challenging in a fragmented urban landscape in which many aquatic habitats are highly modified. The matrix habitat quality is therefore critical for the persistence and breeding success of such species in urban wetlands.

Another factor that affects the dispersal potential of dytiscid species is accessibility from a suitable source population. Some species that are known to be good fliers and which occurred in up to half of the study sites (Appendix 3), seemed only able to utilize ponds with an impermeable surface of less than $30 \%$ in the buffer zone. These species include the two Dytiscus spp., Ilybius ater, and Cybister lateralimarginalis (Fig. 3a). Their absence from ponds in highly urbanised areas may be due to both poor capacity to disperse through the urban matrix and the long distance between source populations and our study ponds. This will be studied further in future research.

\section{The responses of dytiscids to pond characteristics}

We tested the effects of steepness of the pond margin and presence of fish. Steepness of the margin negatively affected both species richness and abundance, in accordance with the results of Nilsson et al. (1994), who found that dytiscid assemblages were richer and more 
abundant in shallow than in steep margins of their study lakes. Juliano (1991) suggested that shallow margins provide refuge from large predatory invertebrates, such as dragonfly larvae. Our study suggests that dytiscids seek shelter in shallower margins to avoid fish, because the effect of margin steepness on dytiscid species richness is stronger in ponds with fish (Fig. 2c) than ponds without fish (Fig. 2d). In the modelling of dytiscid diversity in fishless ponds with a margin steeper than $35^{\circ}$, the predictions of this study may be unreliable due to the scarcity of observations from ponds with steep margins. Only one fishless pond had a steep margin (approximately 58 ${ }^{\circ}$ ) around one third of its perimeter. We excluded the three trap results from that pond from the analysis because they were outliers. Our results suggest that the dytiscid species recorded in our study ponds prefer gently sloping margins, even in ponds without fish.

Margin steepness is associated with many abiotic and biotic characteristics of a pond, including water depth and the occurrence of aquatic vegetation. Most of the dytiscid species recorded in this study prefer shallower habitats with dense vegetation (Nilsson and Holmen 1995; Nilsson and Söderberg 1996). Vegetation provides them with cover from predators, sites for oviposition, and food sources for some species (Yee 2010; Gioria et al. 2010; Frelik 2014a). The occurrence of vegetation, however, is minimal in deep water compared to shallow areas of a water body, due to poor light penetration (Weisner 1991). Because steepness of the margin, pond depth and density of vegetation are generally correlated, it is difficult to distinguish between their effects on macroinvertebrates (Gioria 2014). Whilst steepness of the pond margin could not be dropped from our optimal models, the negative effects of margin steepness had no statistical significance on dytiscid species richness nor abundance. We suggest that these negative effects are indirect and that steepness of the pond margin affects dytiscids indirectly through its correlation with the depth of water and the occurrence of aquatic vegetation, which we will test in future studies.

The fish species in our ponds were all predatory fish that feed on invertebrates, and we found that their presence negatively affects dytiscid diversity. Medium to large-sized dytiscid species, such as Ilybius spp. and Dytiscus spp., seemed more capable of coexisting with fish than small-sized species, such as Hydroporus spp. and Hyphydrus ovatus (Fig. 3b), possibly because of their different ecological roles in freshwater ecosystems. Small-sized dytiscids feed on detritus and invertebrates and are the prey of fish, and these species seem to prefer sites that are free of predatory fish (Brodin et al. 2006). Medium and large-sized dytiscids, such as Agabus spp. and Dytiscus spp., have a better tolerance to predatory fish than small-sized dytiscids, because they are predators of both invertebrates and vertebrates, including young fish (Liao's personal observation; Frelik 2014b). It is also likely that the predatory behaviour of the fish will change throughout the season, as the fish grow in size, enabling them to prey on larger dytiscids. The presence of fish seems to alter the community composition of dytiscids, as well as that of other macroinvertebrates, such as dragonflies (Johansson and Brodin 2003). Although the presence of fish resulted in lower dytiscid diversity in our study, some Odonata species, such as Erythromma najas, have higher abundance in waters with, than without fish (Johansson and Brodin 2003). The presence of aquatic habitats both with and without fish can enhance biodiversity at the landscape level and benefit a variety of taxa. An urban landscape with heterogeneous habitats can thus support a higher aquatic biodiversity than a landscape with homogeneous wetland habitats.

In one of our study ponds, the Prussian carp (Carassius gibelio), an invasive alien species in Finland, was introduced for management purposes; the garden managers considered that the fish would keep the pond water clear (private communication, Leni 
Hyttinen). In our study, we used the presence or absence of fish as a binary factor in the model and all ponds with fish under the category "fish", irrespective of the fish species and we did not analyse the effects of different fish species and their abundance on dytiscids, due to insufficient data. In future studies, we plan to investigate these effects on urban dytiscids and other aquatic macroinvertebrates, for the purpose of developing management recommendations.

\section{Conclusion}

Our study suggests that urbanization has a negative effect on dytiscid species richness, probably due to reduced matrix permeability for dispersal, the loss of natural features of ponds, such as soft edges and the balanced relationship between predators and prey. Loss and degradation of other wetlands are also likely to affect the dytiscid fauna of urban regions. Still, urban wetlands can support diverse dytiscid assemblages.

Our recommendations for supporting dytiscid diversity in urban regions are:

1. maintain favourable pond characteristics, such as gentle margin slopes and vegetated and soft, rather than hard margins;

2. maintain areas of open and permeable habitat adjacent to ponds, to facilitate dispersal between ponds, and supplementary wet habitats to support communities of aquatic invertebrates;

3. exclude fish from some ponds;

4. in ponds that do contain populations of predatory fish, ensure that there are shallow margins and vegetation as protective cover for dytiscids and other macroinvertebrates.

Our findings suggest that attention to small-scale elements of naturalness, such as vegetated, soft and gently sloping pond margins in this case, can contribute significantly to the conservation of biodiversity. In future studies, we plan to investigate how dytiscid diversity is affected by other spatial and environmental factors, such as distance between populations, road effects, water depth, and aquatic vegetation cover. We also plan to study the effects of fish species and abundance on dytiscids and other macroinvertebrates to provide further practical management recommendations.

Acknowledgements Open access funding provided by University of Helsinki including Helsinki University Central Hospital. Our research was supported by Chinese Scholarship Council (Grant 201707960009 to WL). We thank Joel Jalkanen for helping obtain data of impermeable surface of Helsinki Metropolitan Area, and Anders Nilsson for his constructive comments on dytiscids. We thank the two anonymous reviewers for their constructive comments.

Open Access This article is licensed under a Creative Commons Attribution 4.0 International License, which permits use, sharing, adaptation, distribution and reproduction in any medium or format, as long as you give appropriate credit to the original author(s) and the source, provide a link to the Creative Commons licence, and indicate if changes were made. The images or other third party material in this article are included in the article's Creative Commons licence, unless indicated otherwise in a credit line to the material. If material is not included in the article's Creative Commons licence and your intended use is not permitted by statutory regulation or exceeds the permitted use, you will need to obtain permission directly from the copyright holder. To view a copy of this licence, visit http://creativecommons.org/licenses/by/4.0/.

Author contributions WL designed the study, collected and analysed the data, and led the writing. SV and $\mathrm{JN}$ revised the manuscript critically for important intellectual contents and structure. All authors gave final approval for publication. 


\section{Appendix 1}

The calculation of the numbers of traps set in each study pond.

The shoreline length of our studied ponds varies from 59 to $559 \mathrm{~m}$. We set 5 traps in the pond with the shortest shoreline, and 15 traps in the pond with the longest. The number of traps set in other ponds is calculated below:

$$
\text { Number of Traps }=0.02 \times \text { Shoreline Length }+3.82
$$

The number of traps is rounded as an integer.

\section{Appendix 2}

The calculation of pond margin steepness.

We estimated pond margin steepness, i.e. the angles $\left(\theta_{i j k}\right)$, at distance $0.5 \mathrm{~m}, 1.0 \mathrm{~m}$, $1.5 \mathrm{~m}$, and $2.0 \mathrm{~m}$ from the shore.

$$
\theta_{i j k}=\arctan \left(\text { Depth }_{i j k} / k\right)
$$

where $\theta_{i j k}$ is the angle between water surface and the pond bottom point $k$ at site $i$ and pond $j, \mathrm{k}=50 \mathrm{~cm}, 100 \mathrm{~cm}, 150 \mathrm{~cm}, 200 \mathrm{~cm}$.

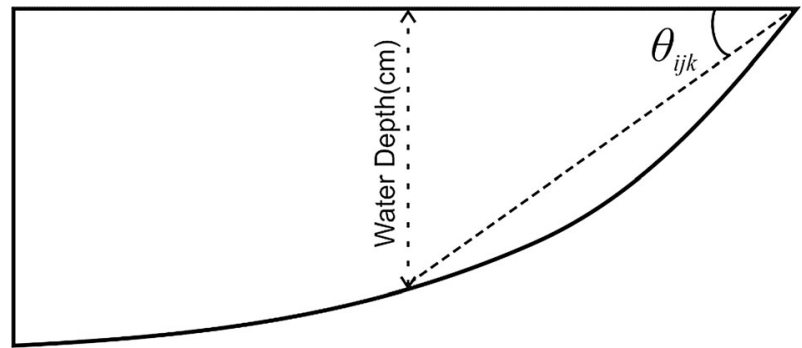

\section{Appendix 3}

Full models and model selection of the GLMMs.

The full GLMM Poisson model for the dytiscid species richness data is described below:

$$
\begin{gathered}
Y_{i j k} \sim \operatorname{Poisson}\left(\mu_{i j k}\right) \\
\mathrm{E}\left(Y_{i j k}\right) \sim \mu_{i j k} \\
\log \left(\mu_{i j k}\right)=\alpha+\beta_{1} \times \text { UR500 }_{i j k}+\beta_{2} \times \text { Steepness }_{i j k}+\beta_{3} \times \text { Fish_situation }_{i j k}+\beta_{4} \\
\times \text { Steepness }_{i j k} \times \text { Fish_situation }_{i j k}+\varepsilon_{i}+\tau_{i j}
\end{gathered}
$$

where the $k$ th species richness observation in pond $j$ at site $i, Y_{i j k}$, is Poisson distributed with mean $\mu_{i j k}$. The covariates are the standardised the proportion of impermeable surface 
within the $500 \mathrm{~m}$ buffer zone $\left(U R 500_{i j k}\right)$, the standardized margin steepness at $1.0 \mathrm{~m}$ from the shore $\left(\right.$ Steepness $\left._{i j k}\right)$, the presence or absence of fish $\left(\right.$ Fish_situation $\left._{i j k}\right)$, and the interactions between Steepness $s_{i j k}$ and Fish_situation ${ }_{i j k}$. The term $\alpha$ is the intercept and the terms $\beta_{1}, \beta_{2}, \beta_{3}$ and $\beta_{4}$ are the parameters of the covariates. The random effects are two-way nested. The term $\varepsilon_{i}$ is site as a random effect and the term $\tau_{i j}$ is pond as a random effect. We assume both random effects are normally distributed with mean 0 and variance $\sigma_{\varepsilon}$ and $\sigma_{\tau}$ respectively.

The full Poisson GLMM for the dytiscid abundance data is as follows:

$$
\begin{gathered}
Y_{k l} \sim \text { Poisson }\left(\mu_{l m n}\right) \\
E\left(Y_{l m n}\right) \sim \mu_{l m n} \\
\log \left(\mu_{l m n}\right)=\omega+\gamma_{1} \times{\text { UR } 500_{l m n}+\gamma_{2} \times \text { Steepness }_{l m n}+\gamma_{3} \times \text { Fish_situation }_{\text {lmn }}+\gamma_{4}}^{\times \text {Steepness }_{l m n} \times \text { Fish_situation }_{\text {lmn }}+a_{l}+b_{l m}}
\end{gathered}
$$

where the $n^{\text {th }}$ dytiscid abundance observation in the pond $m$ at site $l, Y_{l m n}$, follows a Poisson distribution. The term $\omega$ is the intercept and the terms $\gamma_{1}, \gamma_{2}, \gamma_{3}$ and $\gamma_{4}$ are the parameters of the covariates. The random effects, site $\left(a_{l}\right)$ and the ponds $\left(b_{l m}\right)$, are two-way nested and assumed to be normally distributed with mean 0 and variance $\sigma_{a}$ and $\sigma_{b}$ respectively.

The "drop1" command in R suggested not dropping any covariates in the full model of dytiscid species richness. In the model of dytiscid abundance, the covariate of urbanisation rate was suggested to be dropped out from the full model. We ran the models and applied an ANOVA to test the differences between the two models with the lowest AICs.

Model 2:

$$
\begin{aligned}
\log \left(\mu_{l m n}\right)= & \omega+\gamma_{2} \times \text { Steepness }_{l m n}+\gamma_{3} \times \text { Fish_situation }_{l m n}+\gamma_{4} \times \text { Steepness }_{l m n} \\
& \times \text { Fish_situation }_{l m n}+a_{l}+b_{l m}
\end{aligned}
$$

The ANOVA test of the two models:

\begin{tabular}{llll}
\hline Models & Degrees of freedom & AIC & $p$-value \\
\hline Model 2 & 6 & 721.76 & \\
Full model & 7 & 721.86 & 0.167 \\
\hline
\end{tabular}

Model 2 has slightly smaller AIC values, but there is no significant difference between the two models. The effect of urbanisation in Model 1 is insignificant $(p=0.153)$ and can only generate $49 \%$ zeros. Model 2 has a smaller AIC and can generate similar amounts of zeros $(51 \%)$ to the observed data; thus we chose the simpler model as our optimal model.

\section{Appendix 4}

Explanation of abbreviated species names in Fig. 3, the number of the sites (out of the 10 study sites), and minimum and maximum proportion of impermeable surfaces of the ponds in which each species appeared. The symbol " on the NMDS figures; the three species have the same position in the NMDS figures, which is near the position of Clemnius decoratus. 


\begin{tabular}{lllll}
\hline Abbreviation & Species name & Numbers of sites & \multicolumn{2}{l}{ Proportion of impermeable surface } \\
\cline { 4 - 5 } & & & Min $(\%)$ & Max (\%) \\
\hline Acca & Acilius canaliculatus & 5 & 20.46 & 43.00 \\
Acsul & A. sulcatus & 4 & 18.64 & 43.00 \\
Agaff & Agabus affinis & 1 & 15.95 & 22.13 \\
Agcon & Ag. congener & 2 & 15.95 & 22.60 \\
Agstu & Ag. sturmii & 5 & 18.16 & 56.41 \\
Colypay & Colymbetes paykulli & 1 & 18.64 & 22.13 \\
Cybister & Cybister lateralimarginalis & 1 & 22.13 & 22.13 \\
Dycircum & Dytiscus circumcinctus & 4 & 18.64 & 37.42 \\
Dymarg & D. marginalis & 5 & 22.60 & 37.42 \\
Grapaus & Graphoderus austriacus & 1 & 22.13 & 23.32 \\
Grapcin & G. cinereus & 1 & 37.42 & 37.42 \\
Grapzon & G. zonatus & 1 & 20.46 & 22.60 \\
Grapgra & Graptodytes granularis & 1 & 22.60 & 22.60 \\
Hydasemi & Hydaticus seminiger & 4 & 15.95 & 43.00 \\
Hydroan & Hydroporus angustatus & 1 & 15.95 & 41.18 \\
Hydrodi $•$ & H. discretus & 1 & 22.13 & 22.13 \\
Hydroinc & H. incognitus & 3 & 18.64 & 43.00 \\
\hline
\end{tabular}

Explanation of abbreviated species names in Fig. 3, the number of the site, and minimum and maximum proportion of impermeable surface of the pond that each species occurred in.

\begin{tabular}{lllll}
\hline Abbreviation & Species name & Numbers of site & \multicolumn{2}{l}{ Proportion of Impermeable Surface } \\
\cline { 5 - 5 } & & & Min (\%) & Max (\%) \\
\hline Hydrome & H. memnonius & 1 & 20.46 & 20.46 \\
Hydron & H. notatus & 2 & 15.95 & 20.46 \\
Hydropalu & H. palustris & 3 & 15.95 & 41.18 \\
Hydropube & H. pubescens & 2 & 22.60 & 31.31 \\
Hydrostr & H. striola & 2 & 15.9 & 41.18 \\
Clede & Clemnius decoratus & 3 & 15.95 & 43.00 \\
Hygrimpres & Hygrotus impressopunctatus & 1 & 18.64 & 28.04 \\
Hygrinae & Hyg. inaequalis & 4 & 15.95 & 43.00 \\
Hyphyova & Hyphydrus ovatus & 2 & 20.46 & 27.07 \\
Ilyangu & Ilybius angustior & 1 & 28.04 & 28.04 \\
Ilyater & I. ater & 4 & 18.64 & 43.00 \\
Ilycr & I. crassus & 2 & 15.95 & 43.00 \\
Ilyfuligi & I. fuliginosus & 1 & 37.42 & 37.42 \\
Ilyg & I. guttiger & 1 & 15.95 & 18.64 \\
Ilyquadri & I. quadriguttatus & 3 & 20.46 & 43.00 \\
Ilysubae & I. subaeneus & 2 & 28.04 & 37.81 \\
\hline
\end{tabular}




\begin{tabular}{lllll}
\hline Abbreviation & Species name & Numbers of site & \multicolumn{2}{l}{ Proportion of Impermeable Surface } \\
\cline { 5 - 5 } & & & Min (\%) & Max (\%) \\
\hline Ilysubtilis & I. subtilis & 1 & 27.07 & 27.07 \\
Ilyw & I. wasastjernae & 1 & 22.13 & 22.13 \\
Rhex & Rhantus exsoletus & 5 & 20.46 & 37.81 \\
Rhf & R. frontalis & 3 & 18.16 & 31.31 \\
Rhsu & R. suturellus & 1 & 20.4 & 20.46 \\
Suphdor & Suphrodytes dorsalis & 2 & 22.60 & 27.65 \\
\hline
\end{tabular}

\section{References}

Bilton DT (2014) Dispersal in dytiscidae. In: Yee DA (ed) Ecology, systematics, and the natural history of predaceous diving beetles (Coleoptera: Dytiscidae). Springer, Dordrecht, pp 387-407

Brodin T, Johansson F, Bergsten J (2006) Predator related oviposition site selection of aquatic beetles (Hydroporus spp.) and effects on offspring life-history. Freshw Biol 51:1277-1285. https://doi.org/10. 1111/j.1365-2427.2006.01563.x

Brooks ME, Kristensen K, van Benthem KJ, Magnusson A, Berg CW, Nielsen A, Skaug HJ, Machler M, Bolker BM (2017) glmmTMB balances speed and flexibility among packages for zero-inflated generalized linear mixed modeling. R J 9:378-400

Carter M (2015) Wetlands and health: how do urban wetlands contribute to community wellbeing? In: Finlayson C, Horwitz P, Weinstein P (eds) Wetlands and human health. Springer, Dordrecht, pp 149-167

Concepción ED, Moretti M, Altermatt F, Nobis MP, Obrist MK (2015) Impacts of urbanisation on biodiversity: the role of species mobility, degree of specialisation and spatial scale. Oikos 124:1571-1582. https://doi.org/10.1111/oik.02166

Culler LE, Ohba SY, Crumrine P (2014) Predator-prey interactions of dytiscids. In: Yee DA (ed) Ecology, systematics, and the natural history of predaceous diving beetles (Coleoptera: Dytiscidae). Springer, Dordrecht, pp 363-386

Della Bella V, Mancini L (2009) Freshwater diatom and macroinvertebrate diversity of coastal permanent ponds along a gradient of human impact in a Mediterranean eco-region. In: Oertli B, Céréghino R, Biggs J, Declerck S, Hull A, Miracle M (eds) Pond conservation in Europe. Springer, Dordrecht, pp 181-197

Dolmen D, Solem JO (2002) Life history of Ilybius fenestratus (Fabricius)(Coleoptera, Dytiscidae) in a central Norwegian lake. Aquatic Insects 24:199-205. https://doi.org/10.1076/aqin.24.3.199.8118

Eggermont H, Balian E, Azevedo J et al (2015) Nature-based solutions: new influence for environmental management and research in Europe. GAIA Ecol Perspect Sci Soc 24:243-248

Eriksson U (1972) The invertebrate fauna of the Kilpisjarvi area, Finnish Lapland 10. Dytiscidae. Acta Soc Pro Fauna Et Flora Fennica 80:121-160

Frelik A (2014a) Food of adult diving beetles Colymbetes fuscus (Linnaeus, 1758) and C. striatus (Linnaeus, 1758) (Coleoptera: Dytiscidae) in the Zehlau Peatbog and in oxbow lakes and fens (the Biebrza Marshes). Pol J Entomol 83:171-180. https://doi.org/10.2478/pjen-2014-0012

Frelik A (2014b) Predation of adult large diving beetles Dytiscus marginalis (Linnaeus, 1758), Dytiscus circumcinctus (Ahrens, 1811) and Cybister lateralimarginalis (De Geer, 1774) (Coleoptera: Dytiscidae) on fish fry. Oceanol Hydrobiol Stud 43:360-365. https://doi.org/10.2478/s13545-014-0153-8

Gioria M (2014) Habitats. In: Yee DA (ed) Ecology, systematics, and the natural history of predaceous diving beetles (Coleoptera: Dytiscidae). Springer, Dordrecht, pp 307-362

Gioria M, Schaffers A, Bacaro G, Feehan J (2010) The conservation value of farmland ponds: predicting water beetle assemblages using vascular plants as a surrogate group. Biol Conserv 143:1125-1133. https://doi.org/10.1016/j.biocon.2010.02.007

Goertzen D, Suhling F (2013) Promoting dragonfly diversity in cities: major determinants and implications for urban pond design. J Insect Conserv 17:399-409. https://doi.org/10.1007/s10841-012-9522-z 
Hamer AJ, Parris KM (2011) Local and landscape determinants of amphibian communities in urban ponds. Ecol Appl 21:378-390. https://doi.org/10.1890/10-0390.1

Hassall C (2014) The ecology and biodiversity of urban ponds. Wiley Interdiscip Rev Water 1:187-206. https://doi.org/10.1002/wat2.1014

Hassall C, Anderson S (2015) Stormwater ponds can contain comparable biodiversity to unmanaged wetlands in urban areas. Hydrobiologia 745:137-149. https://doi.org/10.1007/s10750-014-2100-5

Hill MJ, Wood PJ (2014) The macroinvertebrate biodiversity and conservation value of garden and field ponds along a rural-urban gradient. Fundam Appl Limnol 185:107-119. https://doi.org/10.1127/fal/ 2014/0612

Hill MJ, Biggs J, Thornhill I, Briers RA, Gledhill DG, White JC, Wood PJ, Hassall C (2017) Urban ponds as an aquatic biodiversity resource in modified landscapes. Glob Chang Biol 23:986-999. https://doi.org/ 10.1111/gcb.13401

Holtmann L, Juchem M, Brüggeshemke J, Möhlmeyer A, Fartmann T (2018) Stormwater ponds promote dragonfly (Odonata) species richness and density in urban areas. Ecol Eng 118:1-11. https://doi.org/10. 1016/j.ecoleng.2017.12.028

HYS (2016) Seudullinen maanpeiteaineiston. https://www.hsy.fi/fi/asiantuntijalle/avoindata/Sivut/ AvoinData.aspx?dataID=38. Accessed 12 Nov 2018

Iversen LL, Rannap R, Thomsen PF, Kielgast J, Sand-Jensen K (2013) How do low dispersal species establish large range sizes? The case of the water beetle Graphoderus bilineatus. Ecography 36:770-777. https://doi.org/10.1111/j.1600-0587.2013.00001.x

Johansson F, Brodin T (2003) Effects of fish predators and abiotic factors on dragonfly community structure. J Freshw Ecol 18:415-423. https://doi.org/10.1080/02705060.2003.9663977

Juliano SA (1991) Changes in structure and composition of an assemblage of hydroporus species (Coleoptera: Dytiscidae) along a pH gradient. Freshw Biol 25:367-378

Kehl S (2014) Morphology, anatomy, and physiological aspects of dytiscids. In: Yee D (ed) Ecology, systematics, and the natural history of predaceous diving beetles (Coleoptera: Dytiscidae). Springer, Dordrecht, pp 173-198

Lubertazzi MAA, Ginsberg HS (2010) Emerging dragonfly diversity at small Rhode Island (USA) wetlands along an urbanization gradient. Urban Ecosyst 13:517-533. https://doi.org/10.1007/s11252-010-01338

Lundkvist E, Landin J, Karlsson F (2002). Dispersing diving beetles (Dytiscidae) in agricultural and urban landscapes in south-eastern Sweden. Ann Zool Fennici, 39: 109-123.

Maksimović Č, Kurian M, Ardakanian R (2015) Rethinking infrastructure design for multi-use water services. Springer, New York

Meutter FVD, Meester LD, Stoks R (2007) Metacommunity structure of pond macroinvertebrates: effects of dispersal mode and generation time. Ecology 88:1687-1695. https://doi.org/10.1890/06-0333.1

Muñoz PT, Torres FP, Megías AG (2015) Effects of roads on insects: a review. Biodivers Conserv 24(3):659-682. https://doi.org/10.1007/s10531-014-0831-2

Murray CG, Kasel S, Loyn RH, Hepworth G, Hamilton AJ (2013) Waterbird use of artificial wetlands in an Australian urban landscape. Hydrobiologia 716:131-146. https://doi.org/10.1007/s10750-013-1558-X

Nesshöver C, Assmuth T, Irvine KN et al (2017) The science, policy and practice of nature-based solutions: An interdisciplinary perspective. Sci Total Environ 579:1215-1227. https://doi.org/10.1016/j.scitotenv. 2016.11.106

Nilsson AN (1997) On flying Hydroporus and the attraction of $\mathrm{H}$. incognitus to red car roofs. Latissimus 9:12-16

Nilsson AN, Hájek J (2018) A world catalogue of the family Dytiscidae, or the diving beetles (Coleoptera, Adephaga), version 1.I.2018

Nilsson AN, Holmen M (1995) The aquatic adephaga (Coleoptera) of the Fennoscandia and Denmark. II. Dytiscidae: II-Dytiscidea. E. J. Brill, Leiden

Nilsson AN, Söderberg H (1996) Abundance and species richness patterns of diving beetles (Coleoptera, Dytiscidae) from exposed and protected sites in 98 northern Swedish lakes. Hydrobiologia 321:83-88. https://doi.org/10.1007/BF00018680

Nilsson AN, Svensson BW (1995) Assemblages of dytiscid predators and culicid prey in relation to environmental factors in natural and clear-cut boreal swamp forest pools. Hydrobiologia 308:183-196. https://doi.org/10.1007/BF00006870

Nilsson AN, Elmberg J, Sjöberg K (1994) Abundance and species richness patterns of predaceous diving beetles (Coleoptera, Dytiscidae) in Swedish lakes. J Biogeogr 21:197-206

Noble A, Hassall C (2015) Poor ecological quality of urban ponds in northern England: causes and consequences. Urban Ecosyst 18:649-662. https://doi.org/10.1007/s11252-014-0422-8 
R Core Team (2018) R: a language and environment for statistical computing. R Foundation for Statistical Computing, Vienna

Rassi P, Karjalainen S, Clayhills T (2015) Kovakuoriaisten maakuntaluettelo 2015: provincial list of Finnish Coleoptera 2015. Luonnontieteellinen keskusmuseo Luomus, Helsinki

Oksanen J, Blanchet FG, Kindt R et al (2018) vegan: Community Ecology Package. R package version $2.5-3$

Sharley DJ, Sharp SM, Marshall S, Jeppe K, Pettigrove VJ (2017) Linking urban land use to pollutants in constructed wetlands: Implications for stormwater and urban planning. Landsc Urban Plan 162:80-91. https://doi.org/10.1016/j.landurbplan.2016.12.016

Schäfer ML, Lundkvist E, Landin J, Persson TZ, Lundström JO (2006) Influence of landscape structure on mosquitoes (Diptera: Culicidae) and dytiscids (Coleoptera: Dytiscidae) at five spatial scales in Swedish wetlands. Wetlands 26:57-68

Stork NE, Stone M, Sam L (2016) Vertical stratification of beetles in tropical rainforests as sampled by light traps in North Queensland, Australia. Austral Ecol 41:168-178. https://doi.org/10.1111/aec.12286

Sun R, Chen A, Chen L, Lü Y (2012) Cooling effects of wetlands in an urban region: the case of Beijing. Ecol Indic 20:57-64. https://doi.org/10.1016/j.ecolind.2012.02.006

Tzoulas K, Korpela K, Venn S, Yli-Pelkonen V, Kaźmierczak A, Niemela J, James P (2007) Promoting ecosystem and human health in urban areas using green infrastructure: a literature review. Landsc Urban Plan 81:167-178. https://doi.org/10.1016/j.landurbplan.2007.02.001

Verberk WC, Siepel H, Esselink H (2008) Life-history strategies in freshwater macroinvertebrates. Freshw Biol 53:1722-1738. https://doi.org/10.1111/j.1365-2427.2008.02035.x

Vierikko K, Niemelä J (2016) Bottom-up thinking-identifying socio-cultural values of ecosystem services in local blue-green infrastructure planning in Helsinki, Finland. Land Use Policy 50:537-547. https:// doi.org/10.1016/j.landusepol.2015.09.031

Völker S, Kistemann T (2015) Developing the urban blue: comparative health responses to blue and green urban open spaces in Germany. Health \& Place 35:196-205. https://doi.org/10.1016/j.healthplace. 2014.10.015

Völker S, Baumeister H, Classen T, Hornberg C, Kistemann T (2013) Evidence for the temperaturemitigating capacity of urban blue space-a health geographic perspective. Erdkunde 67:355-371. https://doi.org/10.3112/erdkunde.2013.04.05

Wahlberg E, Solbreck C (2013) Hymenoptera flying over a boreal forest landscape. Entomologisk Tidskrift 134:163-171

Wahlroos O, Valkama P, Mäkinen E et al (2015) Urban wetland parks in Finland: improving water quality and creating endangered habitats. Int J Biodivers Sci Ecosyst Serv Manage 11:46-60. https://doi.org/ $10.1080 / 21513732.2015 .1006681$

Weisner SE (1991) Within-lake patterns in depth penetration of emergent vegetation. Freshwater Biol 26:133-142. https://doi.org/10.1111/j.1365-2427.1991.tb00515.x

Yee DA (2010) Behavior and aquatic plants as factors affecting predation by three species of larval predaceous diving beetles (Coleoptera: Dytiscidae). Hydrobiologia 637:33-43. https://doi.org/10.1007/ s10750-009-9982-7

Zalewski M, Wagner I (2008) Ecohydrology of urban aquatic ecosystems for healthy cities. In: Wagner I, Marsalek J, Breil P (eds) Aquatic habitats in sustainable urban water management: science, policy and practice. Taylor and Francis/Balkema, Leiden, pp 95-106

Zuur AF, Ieno EN (2016) A protocol for conducting and presenting results of regression-type analyses. Methods Ecol Evol 7:636-645. https://doi.org/10.1111/2041-210X.12577

Publisher's Note Springer Nature remains neutral with regard to jurisdictional claims in published maps and institutional affiliations. 